\title{
Locally Advanced Lung Non-Squamous Non-Small Cell Carcinoma
}

National Cancer Institute

\section{Source}

National Cancer Institute. Locally Advanced Lung Non-Squamous Non-Small Cell

Carcinoma. NCl Thesaurus. Code C153200.

Non-squamous non-small cell lung carcinoma that has spread from its original site of growth to nearby tissues or lymph nodes. 